\section{OUTDOOR SPORTS IN PORTO ALEGRE: CHALLENGES AND OPPORTUNITIES}

\author{
ATIVIDADES ESPORTIVAS NA NATUREZA EM PORTO ALEGRE: DESAFIOS E \\ OPORTUNIDADES
}

ACTIVIDADES DEPORTIVAS EN LA NATURALEZA EN PORTO ALEGRE: DESAFIOS Y OPORTUNIDADES

\author{
Alcides Vieira Costa*, Jo Straker**, Alberto Reinaldo Reppold Filho*
}

Keywords:

Exercise.

Nature.

Sports.

Environmental

Administration.

\begin{abstract}
The aim of this study was to analyse the challenges and opportunities of developing outdoor sports in Porto Alegre, Brazil. Twenty-nine interviews were conducted with different stakeholders. Eight observations were conducted while participants were engaged in outdoor sports. The results indicated that selecting appropriate sites in terms of safe practice and prevention of overuse of the sites represent challenges; and the potential for the involvement of participants, instructors and local communities in the maintenance of the natural environment and in the management of outdoor sports represent opportunities. In conclusion this study demonstrated that outdoor sports must be avoided in some areas of the city. However, through proactive management and promotion of outdoor sports opportunities can mitigate the challenges.
\end{abstract}

Palavras chave:

Exercício.

Natureza.

Esportes.

Administração

ambiental.

Palabras clave: Ejercicios.

Naturaleza.

Deportes.

Administración ambiental.
Resumo: Este estudo teve por objetivo analisar os desafios e as oportunidades para 0 desenvolvimento de atividades esportivas na natureza em Porto Alegre, Brasil. Foram realizadas 29 entrevistas com representantes de organizações ligadas a estas atividades e oito observações de grupos de praticantes. Os resultados indicaram que a escolha de locais apropriados para a realização destas atividades e medidas para evitar a superlotação dos locais de prática, representam desafios; e o potencial de envolvimento de praticantes, instrutores e comunidades locais na manutenção do meio natural e na gestão de atividades esportivas na natureza, representam oportunidades. Em conclusão, o estudo demonstrou que existem áreas da cidade em que essas atividades devem ser evitadas. No entanto, por meio de gerenciamento proativo e promoção de atividades esportivas na natureza as oportunidades podem mitigar os desafios.

Resumen: El objetivo de este estudio fue analizar los desafíos y oportunidades de desarrollar actividades deportivas en la naturaleza en Porto Alegre, Brasil. Veintinueve entrevistas fueron conducidas con diferentes partes interesadas. Se realizaron ocho observaciones mientras los participantes se dedicaban a las actividades. Los resultados indicaron que la selección de sitios apropiados en términos de prácticas seguras y prevención de hacinamiento representa un desafío; y el potencial para la participación de practicantes, instructores y comunidades locales en el mantenimiento del medio ambiente natural y en la gestión de actividades deportivas en la naturaleza representa oportunidades. En conclusión, este estudio demostró que estas actividades deben evitarse en algunas áreas de la ciudad. Sin embargo, a través de una gestión proactiva y la promoción de actividades deportivas al aire libre, las oportunidades pueden mitigar los desafíos.
*Universidade Federal do Rio Grande do Sul. Porto Alegre, RS, Brasil. E-mail: professoralcides@yahoo.com; areppold@portoweb.com.br

${ }^{* *}$ Christchurch Polytechnic Institute of Technology. Christchurch, New Zealand.

E-mail: strakerstaite@gmail.com

Recebido em: 30-04-2018

Aprovado em: 09-05-2019

Publicado em: 24-06-2019

DOI:

https://doi.org/10.22456/1982-8918.82423

(c) (1) (8) Licence 


\section{INTRODUCTION}

Outdoor sports attract a wide range of participants to enjoy the natural environment and to engage in a variety of competitive and recreation pursuits. According to Gonson et al. (2017), there is a growing number of participants in outdoor activities worldwide. In recent decades, people of different social and economic backgrounds have become involved in outdoor sports. Consequently, these activities are diversifying and increasing in number.

The growing demand for a more intimate risk-controlled contact with nature has attracted the attention of the public and private sector, especially the tourism industry. There are also benefits for the participants in outdoor sports and for the natural environment that have been considered by government and non-governmental organizations (NGOs), sport federations and the academic world.

Research suggests that outdoor experiences provide many positive effects such as, stress relief, feelings of happiness and general well-being (CHAO et al., 2015; FROMEL et al., 2017; GODBEY, 2009; MACKERRON; MOURATO, 2013;). Other studies suggest that engaging in outdoor sports increases awareness of environmental issues and helps people develop an appreciation of particular environments (BARKER; DAWSON, 2010). Participation in such activities also provides participants with knowledge and respect for their environments (STRAKER, 2014). Costa and Reppold Filho (2015), Gladwell et al. (2013), MacKerron and Mourato (2013), and Serrano and Petrica (2010) expand on these benefits, stating that outdoor sports can help revitalize some rural areas, engage people in recreational activities, promote satisfying social relationships, allow direct contact with nature, and improve physical and mental health.

However, as the popularity of outdoor sports grows, some of the more fragile sites are becoming irrevocably degraded. Some researchers argue that this popularity can come at a cost, as many popular sites have been exposed to environmental damage (COSTA; REPPOLD FILHO, 2015; ENG; VAN PELT, 2010; OLSON et al., 2017; STRAKER, 2015; TORBIDONI, 2015). Local communities can also become disenfranchised when corporations build infrastructure that is insensitive to their needs, for example, depleting critical water supplies for swimming pools and golf courses.

Hence, when participation in outdoor sports causes environmental degradation and disregard for cultural practices, the value of promoting these activities needs to be examined critically. Like all lifestyle choices, outdoor sports are part of a wider picture of living within the constraints of the planet and although they are often perceived as being environmentally friendly, that is not always the case, the challenges and opportunities for its development have to be evaluated in each situation.

The aim of this study was to analyse the challenges and opportunities of developing outdoor sports in Porto Alegre, Brazil. The city has an area of 496,682 $\mathrm{km}^{2}$. The estimated population for 2017 is over 1.4 million (INSTITUTO BRASILEIRO DE GEOGRAFIA E ESTATÍSTICA, 2017). There are large uninhabited areas, 44 hills, 2 ecological reserves, 9 parks, with 3 conservation units, and a large hydrographic basin, which includes $70 \mathrm{~km}$ of beachfront on the Guaíba Lake and the River Jacuí estuary, with an area of $47.18 \mathrm{~km}^{2}$ (PORTO ALEGRE, 2017, 2003). These constitute rich ecosystems that shelter a diverse range of native fauna and flora. Due to its geographical characteristics, Porto Alegre has several places suitable 
for outdoor sports. This makes the city an interesting case for the study of the challenges and opportunities for the development of outdoor sports in a large Brazilian urban area.

\section{METHOD}

The research is exploratory in nature and a qualitative approach has been used. For data collection, 29 semi-structured interviews were conducted with representatives of three Porto Alegre governmental organizations (Sports Bureau, Tourism Bureau, and Environment Bureau), seven federations representing the outdoor sports that can be practiced in the city (hang gliding, paragliding, mountain biking, rock climbing, hiking, abseiling, orienteering, equestrian activities, kayaking, rafting, sailing, kitesurfing, and windsurfing), three private companies (Big Wall, Vertex Outsider, and Mountain Equipment), three NGOs (Caminhadores.com, for people with disabilities; Mira-Serra and Belém Novo, for the environment), five institutions of higher education (three for sports and physical education, one for outdoor sports and one for geoscience courses), and eight outdoor sports instructors. These representatives were chosen as they are the main stakeholders involved in the development of outdoor sports in Porto Alegre.

The interviews consisted of nine questions on the challenges and opportunities brought about by the promotion of and participation in outdoor sports in Porto Alegre, five questions focused on opportunities for the community and the participants, considering the impact on the environment and on the economy; four questions explored the challenges and focused on the social, physical and health risks that participants are exposed to when in contact with natural environments. The risks of negative environmental impact were also considered.

For data collection, eight observations were also conducted with different groups of people who participate in outdoor sports, including a group with disabilities. Through these observations it was possible to evaluate the challenges and opportunities encountered during the practice of outdoor sports on the hills and beaches of Porto Alegre and in its parks and conservation units. The sites observed, and the number of observations were: Morro do Osso Natural Park (two), Ponta da Cuíca (one), Saint Hilaire Park (one), Botanical Garden (one), Morro da Polícia (one), and Ipanema Beach (two).

Content analysis techniques were used to analyse the information. The data was analysed by integrating the information obtained as a result of the observations and interviews.

\section{RESULTS AND DISCUSSION}

\subsection{CHALLENGES}

The results showed two main challenges for the development of outdoor sports in Porto Alegre: selection of appropriate sites in terms of safe practice due water and land pollution and crime, and prevention of overuse of the sites.

\subsubsection{Selection of appropriate sites for safe practice}

The results of this study showed a major concern with regard to water pollution. The observations carried out in Ponta da Cuíca, Saint Hilaire Park and Ipanema Beach evidenced 
risks of contamination for people doing outdoor sports. In these areas, rubbish, untreated sewing and industrial chemical pollution were identified.

In the interviews, the sailing, and the kayaking and rafting instructors reported cases of people practicing sports in polluted waters that got hepatitis, leptospirosis, skin diseases, among other infections.

An environmental NGO representative that participate in the study said:

I know several people who got different kinds of diseases as ear and eye infections, mainly dermatitis. The participants of outdoor sports have to be aware of this possibility. You can't practice these activities without caution. ${ }^{1}$

A report from the representative of a geoscience course is highly disturbing, as he stated that he had already found casks filled with hazardous industrial pollutants floating in the Guaíba Lake. His report highlights the need for an adequate evaluation, management and control of pollution levels of the practice sites. According to him:

In Brazil, there is no efficient control programs in the industries to prevent dropping chemicals into the water. The participants and people responsible for projects of outdoor sports should always measure it. As long as they have no contact with the water it is ok, but if they fall into the water, they will probably contaminate themselves.

The land in Porto Alegre also showed signs of degradation, offering risks to the participants of outdoor sports. All eight observations evidenced paths with broken glass, rusted metal cans and domestic and industrial rubbish. This situation raises doubts as to whether outdoor sports should be developed in some areas of the city. The representative of the NGO for disabled claimed that: "There is no point in developing outdoor sports, for example in Porto Alegre, trying to show the city potential, if we are taking the participants to places with high levels of pollution, exposing them to many risks."

The results of the study also demonstrated that, due to the lack of public safety in Porto Alegre, there are risks of criminal activity in all areas where outdoor sports take place. There are a number of reports outlining incidents of theft and aggression.

According to a sports and physical education course representative: "In Porto Alegre, since 1989 people are robbed in Morro Santana and surrounding areas. Once, we went there and we were mugged. Yes, there are risks."

An entrepreneur interviewed complements: "In Porto Alegre, we do not deliver our activities as there is a risk regarding anti-social behaviour. We stopped doing the outdoor sports precisely because of the risk; the mugging began and drove away all the participants."

As stated by the geoscience course representative: "Porto Alegre requires a new urban development in order to facilitate the development of outdoor sports. Perhaps the social risk is greater than the benefits associated with the practice of the sport itself."

The reports were many and justified the worry about social risks. An instructor who reacted to a mugging reported the most serious case. He was shot in the assault. Another case refers to mugging on a mountain bike championship where the cyclists were robbed, and their bikes stolen. There is a report involving children in hiking that encountered armed bandits and were not allowed to follow the path.

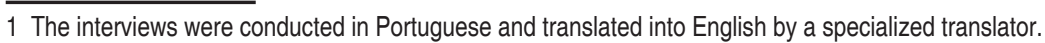


There was a consensus among interviewees that the main risk for the participants of outdoor sports in Porto Alegre is theft and aggression. Godbey (2009) supports this statement arguing that the safety in natural parks and similar areas is a concern for many users, mainly older adults and female. This is mainly because the natural environments are close to the suburban areas with high crime rates.

It is important to note, however, that in Porto Alegre there are safe places, in particular there are a number of areas that offer park-guards. When there is a public or private structure that offers organized activities with preventive actions, social risks decrease considerably. Examples of infrastructures that provide safe outdoor sports for participants are municipal conservation units in Porto Alegre.

According to the representative of the NGO for people with disabilities: "In Itapuã Park there are park-guards and guard patrol. In the municipal conservation units, such as Morro do Osso, we are safe walking with the support of the Environmental Police."

At the observation while hiking at Morro do Osso Natural Park two armed policemen were present all the time, confirming the position of the NGO representative about the safety brought by the presence of guards. Even in a group with twenty people and two armed guards there were the fear of mugging.

\footnotetext{
However, according to the representative of the Porto Alegre Tourism Bureau, even in places with park-guards or safety infrastructure there are risks. She said: "Where there is a public or private structure that offers the activities, the risks are much smaller. However, thefts are very frequent even in spaces where there is a private or public structure."

The sports and physical education course representative supports this position: "I think today is an issue discussed frequently, we risk being mugged anywhere, anytime. There are no more safe spaces or time of the day to be assaulted, we are threatened anywhere, anytime.
}

The participants of outdoor sports are inevitably in contact with the surrounding area and exposed to its elements and risks, so it is necessary to select appropriate sites for safe practice. In many areas, the land and the water are polluted bringing many risks to participants. Therefore, the development of outdoor sports depends on the safety and conservation of certain areas to make the practice possible (GLADWELL et al., 2013; GODBEY, 2009).

\subsubsection{Prevention of sites overuse}

Overuse arose in this research as an important concern for the outdoor sports in Porto Alegre, as in certain places it has the potential to cause severe negative environmental impacts.

The geoscience course representative supports this statement. According to him:

Within certain measures, the outdoor sports are an ally of the idea of living with nature and not against it. However, there are some places where if they are practiced too often and too intensively without proper techniques and infrastructure, they may contribute to the deterioration of the environment.

The observations at Morro do Osso Natural Park and Saint Hilaire Park evidenced the impact of overuse on most of the tracks, since the soil compaction was evident, the vegetation around them was deteriorating and rubbish was found in many places. 
When observing Ponta da Cuíca and Ipanema Beach the impact of overuse seems to be smaller since beaches support a larger flow of people. However, some accesses were degraded, full of rubbish and used for inadequate toileting practices.

The only places observed not impacted by overuse were the Botanical Garden and the Morro da Polícia. The first one was characterized by large, well-maintained and adequate tracks, the number of visitors was controlled and there were adequate number of trash bins and toilet facilities. On the second the tracks were well conserved since this place is not much used for outdoor sports due to the fact that there are areas of high risk of urban violence in both sides of the hill, which make these activities dangerous there.

The rock climbing, hiking and abseiling instructor also indicated that the environmental negative impact brought about by outdoor sports is directly associated to overuse.

The sports and physical education course representative stated how sensible this issue can be:

People practicing outdoor sports cannot enter in such places as if they were the owners of the land. These places exist mainly for those who live there. I think that if you want to go hiking, you must try to interfere as little as possible.

The results of the research in Porto Alegre are supported by Straker (2015), Torbidoni (2015), Gladwell et al. (2013), and Eng and Van Pelt (2010) who suggests that overuse generates negative environmental impacts. According to Costa (2006) and Machado (2005), some outdoor activities lead to a widespread invasion of various natural environments, many of them do not have adequate infrastructure to receive an inordinate flow of people in a short period of time. Eng and Van Pelt (2010) argue that this invasion, when added to the lack of environmental education, causes serious risks of environmental deterioration and upsets the community and residents of the area.

\subsection{OPPORTUNITIES}

According to the study, there are two main opportunities brought about by outdoor sports in Porto Alegre: maintaining the natural environment through participants and local communities' interventions; and the integration of participants, instructors and local communities on the management of outdoor activities.

\subsubsection{Maintenance of the natural environment through participants and local communities' interventions}

According to the results of the study, there are many possible interventions brought about by participants and local communities on the maintenance of the natural areas during the outdoor sports. They can help on keeping well-maintained areas and preventing preying, they can also integrate harmoniously with the natural environment becoming aware of the need to preserve and increase the respect for nature (BELL et al., 2007). Furthermore, participants can assist local authorities and communities on the supervision of the natural areas and monitor certain environmental impacts. communities can be helpful not only to keep well-maintained areas, but also to 
prevent people from preying on them. It can occur through direct interventions and complaints or just by their presence, avoiding negative impacts on fauna and flora or other problems such as landfills. According to one of the entrepreneurs interviewed: "Participants are people who usually care about the natural environments, trying to keep them clean, preventing them from depredations and degradation, somehow exerting a kind of supervision."

Another entrepreneur gave an example:

In the mid-1990s, a hill in the region of Sapucaia do Sul city was used for illegal dumping of garbage by tanneries. The climbers from the cities of Esteio and Sapucaia do Sul made a campaign with the municipalities so that the illegal garbage deposited could be removed.

During the observations of hiking in Morro do Osso Natural Park the concern of many participants with the conservation of the natural environment was clear. Many of them cleaned up the paths bringing the rubbish found and discussed the issue of conservation and maintenance. It was not clear though if the behaviour was influenced or not by the environmental education speech made by the organizers at the beginning of the activities.

Some outdoor sports such as sailing integrate participants harmoniously in the nature. According to the sailing instructor this integration influences the maintenance of the sites and even reverses the environmental degradation of some places. The president of the Sailing Federation supports this statement by saying that sailing increases the respect and sensitizes people for the need to preserve the environment and to intervene positively with it. The sailing instructor adds: "The participants begin to understand the environment in which they practice the activity and respect it, aiming to keep it healthy. When people respect the environment, they consequently support actions that help improve it."

The practice of orienteering also contributes to the maintenance of the environment because it allows locals and participants to see the negative impacts generated in the natural areas. The president of the Orienteering Federation emphasized that participants began to have a better notion of the importance of preservation procedures. According to him: "Most of the time, participants clean up natural areas, preserve fauna and flora and are concerned about being multipliers of environmental preservation ideas and of adequate conservational behaviours.

According to the vice-president of the Hang Gliding and Paragliding Federation, the outdoor sports can be helpful to the environment, not just because the participants enjoy being in direct contact with nature, but also become preservers and intervene directly on its maintenance. The hang gliding and paragliding instructor pointed out another way of environmental preservation and regeneration of degraded natural areas. He stated: "There are events in many regions in which hang gliding and paragliding pilots fly over areas of difficult access to sow seeds of native trees, helping maintain the local flora and, as a result, the fauna."

The geoscience course representative reinforce that the practice of outdoor sports makes it possible to contemplate the beauty of the natural areas and improve environmental awareness, extremely important in today's society. According to him:

Our forests are fragmenting due to the pressure of urban occupation. There should be trails where people could walk from one forest to another. It could keep the idea that these forests cannot be fragmented. It would even be a benefit for their maintenance and rebalance. There is a lot of work to be done in this sense and the outdoor sports could help. 
Overall, participating in and promoting outdoor sports can be an opportunity in maintaining, reversing the degradation and controlling the use of the natural environments. However, to improve benefits an important opportunity is the integration of local community, providers, councils, participants, and instructors in the management of these activities.

The direct intervention of all involved can preserve and even revert the degradation of many natural areas. Through a combination of participation and environmental education, it is possible to learn and teach how to respect nature and disseminate environmental awareness.

By consciously integrating themselves with the natural environments, through educational and facilitation programmes, participants of outdoor sports, instructors and locals can become citizens with some environmental intervention ability. Some studies suggest that people tend to have more environmentally responsible behaviours when they feel connected to the environment (BERNS; SIMPSON, 2009; FISHER, 2002; GONSON et al., 2017; MAYER; FRANTZ, 2004; ROSZAK, 2001). Schultz (2002) defines connectedness as the way individuals include nature within their cognitive representation of self. Connectedness develops as individuals feel part of the natural world and see themselves as part of the wider ecology of the planet.

\subsubsection{Integration of participants, instructors and local communities on the management of outdoor activities}

The need for choosing adequate and safe practice sites and for avoid overuse on outdoor sports is undoubtedly a big concern (GLADWELL et al., 2013; GODBEY, 2009). To overcome these challenges, there is the opportunity to integrate participants, instructors and locals on the management of these activities. The environmental impact planning, well considered regulatory measures, and environmental educational interventions are needed for the sustainable development and management of all outdoor activities (TORBIDONI, 2015; STRAKER, 2014). If so, more ventures would adopt sustainable practices like controlling activities and visitor numbers, building well-designed infrastructures, purchasing environmentally friendly products and involving communities.

Some researchers suggest that when participants, instructors and local communities are closely involved in planning and working on the sport ventures then access to improved infrastructure can help the sustainable development of these communities without undermining the natural and cultural heritage (CHAO et al., 2015; SERRANO; PETRICA, 2010; STRAKER, 2014; TORBIDONI, 2015).

The kitesurfing and windsurfing instructor advocate that all aquatic and nautical activities participants seek the preservation of the water and beaches, spreading environmental awareness. He contended that participants have a direct impact on the management of the natural environment as, whenever possible, they intervene when seeing environmentally harmful practices, increasing the concern about the need for environmental preservation. The instructor argues that: "The sailor warns others of a single cigarette thrown onto the floor. In addition to warning, he explains the correct procedures. The sailor is concerned about the nature and everything that relates to the activity.

Perkins (2010), Mayer et al. (2009), Davis, Green and Reed (2009), Heimlich and Ardoin (2008), Schultz and Tabanico (2007) and Schultz et al. (2005) give support considering that outdoor sports which help build a sense of belonging often support the development of pro-environmental attitudes and actions. However, some research suggests the gap between 
developing pro-environmental values and taking action is much more complex (KOLLMUSS; AGYEMAN, 2002).

The direct interventions from participants, instructors and local communities on the management of the natural areas is important as the need for a better occupation of these areas is evident in the opinion of most interviewees. This was also evidenced in all observations, since rubbish was found almost everywhere, in the bushes, on the beaches, in the lakes and rivers in Porto Alegre.

If outdoor sports participants, instructors and local communities managed these areas, some of these problems could be avoided as they could encourage an adequate behaviour and assist people on taking care of the nature. Barker and Dawson (2010) state that providing information about "environmental issues and knowledge of how to act may be the most effective way to influence attitudes and increase environmental responsible behaviour" (p. 195).

\begin{abstract}
Besides promoting adequate behaviour, according to the orienteering instructor, the mapper, when updating maps, can verify if forests are growing or being degraded. He points out that the mappers, or even the participants and instructors, always report to the authorities when they realize a significant change in the wild, helping the management of these areas. He said: "As maps are used and need to be updated, it is possible to detect changes in vegetation, if the areas are being properly preserved and if there are illegal occupations, burnings or landfills."
\end{abstract}

One of the entrepreneurs interviewed pointed out that the natural areas that are not frequented are more susceptible of environmental degradation as no one notices what has happened in time to take action. The president of the Mountaineering Federation corroborates this position by stating: "Due to the fact that municipalities cannot afford to inspect and manage all natural areas, the occupation of these areas to carry out outdoor sports is a possibility to help in their preservation.

According to the representative of a NGO for disabled, by knowing what is going on, the participants can assist local authorities and communities on the control of the use of the natural areas. He said:

Since 2003, we have been taking pictures and recording the damage done to the environment and forwarding the data to the Environment Bureau, so they are aware of what has been done to the ecosystems and can take the right measures.

The rock climbing, hiking and abseiling instructor and the president of the Mountaineering Federation support this statement explaining that in most areas where outdoor sports are practiced there is no control, by municipalities, of the negative environmental impacts generated. In these areas, participants and local communities end up becoming the managers of the tracks most frequently used, bringing important contributions to the sustainability of these areas, a position also supported by Willis (2002). The two interviewees said that when a particular area is used for rock climbing, hiking and abseiling, participants, tour operators, associations and clubs usually manage it. As a result, there is a tendency for improving the preservation of these areas.

The involvement of experienced participants and instructors in planning, constructing and maintaining facilities and trails is an important contribution for the natural environmental brought about by outdoor sports (TORBIDONI, 2015). Moreover, according to Costa (2006) this involvement improves the quality of the facilities and tracks, providing a better management of the resources. Furthermore, as supported by Machado (2005) and Costa (2005) experienced 
participants and instructors can be crucial on helping to evaluate the load capacity of each area, to find out a proper management planning, to assist staff training and to help on the environmental educational interventions. Consequently, the negative impacts can be minimized, and the educational characteristics of each activity enhanced.

\section{FINAL THOUGHTS}

The increasing range of outdoor sports experiences offered worldwide brings both challenges and opportunities. Although there are many positive personal, social, economic and environmental impacts due to the development of these nature related activities, they can also be responsible for considerable negative environmental impacts and may bring about risks to the participants and local communities.

In Porto Alegre, it is crucial to consider that in some areas there are risks for the participants of outdoor sports due to the high rates of criminality, such as theft and aggression. The natural environments on the rural areas of the city are safer and can be more adequate to the development of outdoor sports, although only in specific places and still offering some social risks. However, there are opportunities brought about by outdoor sports that can mitigate their challenges. Well-maintained natural environments and adequately managed activities result in more sustainable, appropriate and safer practice sites, decreasing overuse and criminal activities. It is also evident that practice sites must be well maintained and managed to protect not only the natural environment but also everyone involved in the activities.

Participants, local communities and municipalities all together can play an important role in the occupancy, maintenance and management of the natural environment in the city. In interaction with public and private sectors, participants, instructors and local communities can take care, preserve, manage and even recover some degraded areas. This opportunity also seems to mitigate the challenge of having to choose adequate and safe practice sites and avoiding overuse, since the better conserved and managed the areas, the more opportunities to the sustainable practice.

In brief, participating in and promoting outdoor sports in Porto Alegre, require special attention on the maintenance of the natural areas and on the management adopted, which needs to be sustainable and harmoniously involve participants, instructors, and local communities. They can be useful in supporting the development of adequate and safe facilities and managing them, encouraging adequate behaviour, as well as supervising the use of the lands. Whenever it is possible, the involvement of other stakeholders must be considered, such as the tour operators, sports federations, NGOs, lecturers, entrepreneurs, instructors, and government representatives.

The simple interaction with nature through outdoor sports does not assure benefits nor opportunities, so it is of the utmost importance to integrate both an educational process and a sustainable management model, which must include everyone directly or indirectly involved in the activities, pay special attention to the negative environmental impacts generated and respect the local culture. 


\section{REFERENCES}

BARKER, Lindsey; DAWSON, Chad. Exploring the relationship between outdoor recreation activities, community participation, and environmental attitudes. In: NORTHEASTERN RECREATION RESEARCH SYMPOSIUM, 2010, Bolton Landing. Proceedings of the 2010 Northeastern Recreation Research Symposium. Bolton Landing: United States Department of Agriculture, 2010. v. 1, p. 190-196.

BELL, Simon et al. Outdoor recreation and nature tourism: a european perspective. Living Reviews in Landscape Research, v. 1, n. 2, p. 1-46, jun. 2007.

BERNS, Gretchen Newhouse; SIMPSON, Steven. Outdoor recreation participation and environmental concern: a research summary. The Journal of Experiential Education, v. 32, n. 1, p. 79-91, aug. 2009

$\mathrm{CHAO}, \mathrm{Hsin}$ Nery et al. Atividades de aventura na natureza e desenvolvimento do comportamento pró-ambiental: análise comparativa entre idosos e condutores. Movimento, v. 21, n. 1, p. 169-180, jan./mar. 2015.

COSTA, Alcides Vieira. Aventura e ensino superior: as AFAN como conteúdo na Universidade Federal do Rio Grande do Sul. In: UVINHA, Ricardo. Turismo de aventura: reflexões e tendências. São Paulo: Aleph, 2005, p. 87-102.

COSTA, Alcides Vieira. 0 potencial das atividades físicas de aventura na natureza em

Porto Alegre: um estudo integrado dos critérios de adequação do local, da infra-estrutura, das contribuições sócio-ambientais e dos riscos. 2006. 228f. Dissertação (Mestrado em Ciências do Movimento Humano) - Escola de Educação Física, Universidade Federal do Rio Grande do Sul, Porto Alegre, Brazil, 2006.

COSTA, Alcides Vieira; REPPOLD FILHO, Alberto Reinaldo. O potencial das atividades físicas de aventura na natureza: as contribuições para o meio ambiente. Revista de Ciencias del Deporte, v. 11, n.1, p. 95-96, may 2015.

DAVIS, Jody; GREEN, Jeffrey; REED, Allison. Interdependence with the environment: commitment, interconnectedness, and environmental behavior. Journal of Environmental Psychology, v. 29, n. 2, p. 173-180, jun. 2009.

DEBARBIEUX, Bernard et al. Tourism in mountain regions: hopes, fears and realities. Geneva: University of Geneva, 2014.

ENG, Ronald; VAN PELT, Julie. Mountaineering: the freedom of the hills. Seattle: The Mountaineers, 2010.

FISHER, Andy. Radical ecopsychology: psychology in the service of life. New York: State University of New York Press, 2002.

FROMEL, Karel et al. Promoting healthy lifestyle and well-being in adolescents through outdoor physical activity. International Journal of Environmental Research and Public Health, v. 14, n. 5, p. 1-15, may 2017.

GLADWELL, Valerie et al. The great outdoors: how a green exercise environment can benefit all. Extreme Physiology \& Medicine, v.2, n.3, p. 2-7, jan. 2013. 
GODBEY, Geoffrey. Outdoor recreation, health, and wellness: understanding and enhancing the relationship. Resources for the Future, v. 1, n. 1, p. 9-21, may 2009. Disponível em: http://www. rff.org/files/sharepoint/Worklmages/Download/RFF-DP-09-21.pdf. Acesso em: 29 nov. 2016.

GONSON, Charles et al. Influence of settings management and protection status on recreational uses and pressures in marine protected areas. Journal of Environmental Management, v. 200, n. 1, p. 170-185, sep. 2017.

HEIMLICH, Joe; ARDOIN, Nicole. Understanding behavior to understand behavior change: a literature review. Environmental Education Research, v. 14, n. 3, p. 215-237, jul. 2008.

INSTITUTO BRASILEIRO DE GEOGRAFIA E ESTATÍSTICA. Cidades, 2017. Disponível em: https://cidades.ibge.gov.br/brasil/rs/porto-alegre/panorama. Acesso em: 15 set. 2017.

KOLLMUSS, Anja; AGYEMAN, Julian. Mind the gap: why do people act environmentally and what are the barriers to pro-environmental behavior? Environmental Education Research, v. 8 , n. 3, p. 239-260, jul. 2002.

MACHADO, Alvaro. Ecoturismo um produto viável: a experiência do Rio Grande do Sul. Rio de Janeiro: SENAC, 2005.

MACKERRON, George; MOURATO, Susana. Happiness is greater in natural environments. Global Environmental Change, v. 23, n. 5, p. 992-1000, aug. 2013.

MAYER, Stephan; FRANTZ, Cynthia McPherson.The connectedness to nature scale: a measure of individuals' feeling in community with nature. Journal of Environmental Psychology, v. 24, n. 4, p. 503-515, jan. 2004.

MAYER, Stephan et al. Why is nature beneficial? The role of connectedness to nature. Environment and Behavior, v. 41, n. 5, p. 607-643, sep. 2009.

OLSON, Lucretia et al. Modeling large-scale winter recreation terrain selection with implications for recreation management and wildlife. Applied Geography, v. 86, n. 1, p. 66-91, sep. 2017.

PERKINS, Helen. Measuring love and care for nature. Journal of Environmental Psychology, v. 30, n. 4, p. 455-463, dec. 2010.

PORTO ALEGRE. Prefeitura de Porto Alegre. Urbanismo, 2017. Disponível em: http://www2. portoalegre.rs.gov.br/spm/default.php?p_secao=289. Acesso em: 20 jan. 2017.

PORTO ALEGRE. Secretaria Municipal de Meio Ambiente. Programa Guaíba Vive, 2003. Disponível em: http://lproweb.procempa.com.br/pmpa/prefpoa/spm/usu doc/projeto orla7.pdf Acesso em: 15 jan. 2017.

ROSZAK, Theodore. The voice of the earth: an exploration of ecopsychology. New York: Simon \& Schuster, 2001.

SCHULTZ, Wesley. Inclusion with nature: the psychology of human-nature relations. In: SCHMUCK, Peter; SCHULTZ, Wesley. Psychology of sustainable development. Boston: Kluwer Academic Publishers, 2002. p. 61-78.

SCHULTZ, Wesley et al. Values and their relationship to environmental concern and conservation behavior. Journal of Cross-Cultural Psychology, v. 36, n. 4, p. 457-475, jul. 2005. 
SCHULTZ, Wesley.; TABANICO, Jennifer. Self, identity, and the natural environment: exploring implicit connections with nature. Journal of Applied Social Psychology, v. 37, n. 6, p. 12191247, may 2007.

SERRANO, João; PETRICA, João. Emergência de novos estilos de vida e sua relação com o meio natural. In: PETRICA, João. Actividades Físicas em Ambiente Natural. Castelo Branco: IPCB, 2010. p. 7-15.

STRAKER, Jo. Meanings of 'the outdoors': shaping outdoor education in Aotearoa New Zealand. Thesis (Doctor of Philosophy, PhD) University of Waikato, Hamilton, New Zealand, 2014.

STRAKER, Jo. Tourism in the outdoors: but whose outdoors? Lusíada. Economia e Empresa, v. 19, n. 1, p. 39-56, jan./jul. 2015.

TORBIDONI, Estela Inés Farías. Minimización de los impactos medioambientales em los eventos deportivos en el medio natural: las marchas de bicicleta todo terreno. Apunts. Educación Física y Deportes, v. 122, n. 4, p. 68-80, oct./dec. 2015.

WILLIS, Mary. Who has the right to recreate? user conflict in the outdoors. New Zealand Journal of Outdoor Education, v. 1, n. 1, p. 60-67, dec. 2002. 